\title{
Political Power and Generational Prospects for the Future
}

Intergenerational inequality could be reaching a critical point in the UK, as in many other countries in Europe. As I have argued in this book, today's young people look set to be the first generation since the children of the Edwardian era with poorer life chances than their parents across a range of life domains. In housing, pensions and welfare benefits, they will almost certainly do worse over their lifetimes than the previous generation. In employment they have generally faced a difficult start to their adult lives, as age-related inequalities in unemployment and pay have risen, and with earnings and job quality for young people now in decline. Over time, many will catch up with their parents' generation in earnings, if not working conditions, but the less qualified are highly likely to fare worse than their parents throughout their lifetimes. It is only in education that we can say that generational opportunities have improved, but even here the benefits will be overshadowed by the declining value of qualifications on the labour market.

Some of the changes in life chances we have observed can be explained in terms of increasing inequalities. Inequalities in general have been rising in most spheres of social and economic life, including in earnings, housing and wealth. These inequalities show up as increasing gaps within age groups but also across age groups. So the gap between the old and the young grows consistently, in all areas, except education. But generational differences are crosscut by social class divisions, which can easily obscure them. And it is important to remember this because political identities and allegiances are influenced, amongst other things, by both social class and generational differences.

(C) The Author(s) 2017

A. Green, The Crisis for Young People, DOI 10.1007/978-3-319-58547-5_8 
The majority of adults in the UK are pessimistic about the prospects for young people and expect that they will do worse over their lifetimes than their parents' generation. An international survey conducted by MORI in 2013 asked respondents: 'To what extent, if at all, do you think that today's youth will have had a better or worse life than their parents generation or will it be the same.' Amongst adults in Great Britain 54 percent responded 'worse' and only 20 percent 'better'. The majority were pessimistic and more so than in most other countries surveyed. But not all young people and not all adults generally see things is this way. The same survey showed 61 percent in Great Britain 'optimistic' about the prospects 'for themselves and their family' over the coming year, with only 13 percent pessimistic. People in Britain tend to be more optimistic about their own future than the prospects for their social group in general. Our CELS survey results suggested that this was particularly true for young people. Better off respondents, not surprisingly, tend to be more optimistic than those worse off.

Many better-off parents who are able to support their children through unpaid internships and help them to buy homes, will deplore the difficulties faced by young people in general but are less likely to see these in terms of generational inequalities. After all, they are doing their best to mitigate the problems within their own families, even though this does nothing to reduce the problems of the less fortunate young people, whose parents are in no position to help. So for many people, wherever they lie on the political spectrum, the problems faced by young people today are the familiar ones of social class inequalities, with growing agerelated inequalities being an additional but only temporary difficulty for young people. Their transitions to adult life will have been prolonged, but the lucky ones and the most 'resilient' will catch up in time.

The perspective is familiar and somehow reassuring, but does not fully capture the gravity of what is happening to the relationship between generations. Where a generation, on average, is likely to do worse than its parents' generation across many key domains and over the whole life course, a very major historical shift is occurring, and one that is unprecedented at least for the last century. We expect each generation to do better than the last. If that is no longer the case, it puts in question our whole notion of historical progress and indeed the viability of the current social and political order. It not only breaches the tacit social contract between generations. It also castes into doubt the socio-economic system which is designed, among other things, to maintain this generational contract. 
When rising social class inequalities become intertwined with widening intergenerational inequality, there is a very large potential pool of people for whom 'the system is not working.' If the current young generation enter middle age in the mid 2020s still struggling to find homes and decent jobs, and if the prospects for those who follow look no better; if inequality is still rising in both wealth and incomes; and if a post-Brexit Britain is still mired in slow growth with high levels of both private and public debt; a political sea change may occur. Ten years from now, when population ageing is beginning to peak, may be a critical turning point. Of course, we do not have a crystal ball and cannot know this for sure. We cannot be certain that the current generation will have suffered a lifetime intergenerational decline for another 40 years. All we can do is to make predictions based on current trends, factoring in different contingencies. But the trends do not look good, either economically or politically.

Britain has barely recovered from the financial crisis of $2007 / 2008$ which brought the most prolonged recession in living memory. Ten years after the onset of this financial cataclysm, GDP per capita has only just regained pre-recession levels; GDP growth remain slow, although currently better than in many OECD countries; business investment is anaemic; productivity improves glacially, and trade deficits are at an historical high. ${ }^{2}$ The drastic financial measures adopted here, as elsewhere, to save the economic system are everywhere running out of road. Quantitative easing and near-zero interest rates, designed to increase liquidity and boost business confidence and consumer demand, seem to have a diminishing impact. Business investment remains stubbornly low, even if consumer demand is sustained by credit card purchasing in the UK. Because investment, both public and private, is so weak Britain's labour productivity remains relatively low-with output per hour worked still lagging France and Germany by a quarter. ${ }^{3}$ This holds back the improvements in wages and living standards which, in any case, now everywhere struggle to track productivity improvements. ${ }^{4}$ Britain's economy remains both sectorally and regionally unbalanced. Little has yet been achieved to rectify the problems which caused the Great Recession in the first place.

Regulators have made banks hold higher capital ratios and the banking system is supposedly more stable, but savings are low and declining, household debt is almost back to pre-recession levels, while the public debt continues to rise. As before the recession, demand remains dependent on high levels of household borrowing, not least through the 
mortgage debt which continues to increase with ever rising house prices. Further artificial boosts to the economy have come through the liberalisation of pensions in 2015 , allowing over- 55 private pension holders to cash in on their pension pots at will. But the benefits will be short-term and come at a price, storing up problems for the future funding of old age.

The same short-termism applies to many of the financial measures used to stave off financial collapse. Quantitative easing enhanced liquidity and demand, temporally, but creates asset bubbles which ramp up the inequality which is a major cause of suppressed demand and persisting low growth in the economy. The less affluent, who spend most of what they earn, have little more to spend, while the richest ten percent, who have captured most of the earnings growth in recent decades, can find little left to buy, and hoard their money, mostly in 'unproductive' property assets. ${ }^{5}$ Meanwhile, efforts to curb excessive pay in the banking sector have failed dismally, with bankers' bonuses now back to the their pre-crisis peak. Whereas many institutions and individuals deemed to have contributed to the US banking collapse in 2008 have been subject to legal proceedings and large financial penalties, few corporate heads have rolled in Britain, and there remains a pervasive culture of dishonest practices in the banking system. ${ }^{6}$

The dysfunctional model of financialised, neo-liberal capitalism, which nearly brought down the global economy, carries on, zombie-like. Short of some final-hour rethink by European leaders on the EU's free labour movement policy-clearly disliked by substantial majorities in the northwest European countries-proponents of Brexit can propose no credible economic alternative. Stripped of the bombast about a new global Britain, we are, in effect, offered the prospect an insular Little Britain, marooned politically and economically somewhere in the mid-Atlantic, and just desperately trying to stay afloat, competing as an offshore tax haven with a race to the bottom on regulation and corporate taxation.

These economic problems are not, of course, unique to Britain. Advanced economies the world over are struggling with ageing populations, high unemployment and slow growth. What Wolfgang Streeck calls the 'three horsemen of contemporary capitalism' - stagnation, debt and inequality-are continuing to stalk the economic and political landscape. ${ }^{7}$ The financialised turbo-capitalism of the 'roaring nineties' and early 2000s begins to look like the last throw of the dice for the model of liberal market capitalism which has dominated the global era. 
For a while it looked like this new model had found a way to transcend the endemic contradictions of the post-industrial world. After the years of declining rates of growth, shrinking investment opportunities, and the 'profits squeeze' which characterised the late Keynesian era and came to a head with the stagflation and oil price hikes of the 1970s, ${ }^{8}$ capitalism managed to reinvent itself in the 1980s. De-regulation of domestic and international markets, including most importantly in finance, combined with the opportunities offered by the new communications and information technologies, brought a surge in world trade and the rise of the mighty new transnational corporations that came to dominate the world economy. Unable to globalise like capital, constrained by domestic political assaults, and with workers vulnerable to the off-shoring of jobs, trades unions were substantially weakened. The labour share of income declined whilst the capital share rose. ${ }^{9}$ Capital found new markets for investment and profit, not least in the service industries which compliant governments were only too happy to privatise. Markets were aggressively expanded, commodifying all areas of life, including those previously deemed more suited to public management. Then, when the end-of-Millennium dot.com bubble burst signalled the failure of the new technologies to deliver the expected productivity gains, financialisation was ramped up to a higher gear, with super-profits now derived through speculative transactions and new financial instruments operating outside of the 'real economy'. With financial speculation focused above all on property, there was a new era of debt-fuelled growth which came to its inevitable demise, as we know, with the 2008 financial crisis.

It is hard now to see where this discredited experiment in finacialised market capitalism can go next. It has failed to solve the problems of economic stagnation and declining rates of productivity growth. The government austerity programmes, enacted almost everywhere in the wake of the crisis, have failed to tackle the problems of rising public debt. Ageing populations, excessive private debt, and ever-rising income inequality all continue to bear down on the demand needed for re-booting growth. There are few areas of social life remaining for profitable marketisation; little room is left for the further exploitation of labour; and the limits of financial speculation have surely been reached. With the increasing corporate take-over of the democratic process, ${ }^{10}$ the marginalisation of counter ideologies to market liberalism, and the weakening of oppositional forces in a global world that structurally favours 
international capital, it is hard to see from where change will come. Even the gradual eastward shift of the global centre of economic gravity ${ }^{11}$ seems unlikely to throw up a new model of capitalism capable of global economic leadership. As Streeck comments: "no force is at hand that could be expected to reverse the three down trends in economic growth, social equality and financial stability and end their mutual reinforcement.' ${ }^{2}$ Whereas historically capitalism has been helped to survive by the constraints imposed on it by non-market forces, institutions and ideologies, these are no longer so effective. Capitalist progress has by now, says Streeck, more or less destroyed any agency capable of stabilising it.

Globalisation was never the one-way historical street described by the globalists. ${ }^{13}$ It has already-let us not forget-gone decisively into retreat at least once, with the eclipse of liberalism during the period of the two world wars. ${ }^{14}$ Now, engulfed by new contradictions, it appears in danger of switching to reverse gear again. 20 years ago two very prescient journalists gave the following millennial warning. '(T)he foremost task of democratic politicians on the threshold of the next century,' they wrote,

will be to restore the state and the primacy of politics over economics. If this is not done, the dramatic fusing together of humanity through technology and trade will soon turn into the opposite and lead to global crackup. ${ }^{15}$

The warnings were not headed - in fact the state and political elites became ever more supine in the face of global corporate power-and we are at this prophetic point now. That globalisation is in crisis was never more evident than in the calamitous events of 2016. Regional war, terrorism, the humanitarian disaster of millions refugees bringing the crisis back home to the West, where in part it originated, all cast a dark shadow over this tragic year. The UK referendum vote for Brexit, and the election of a right-wing, nationalist demagogue to the world's most powerful office, sounded a wake-up call to the liberal order; and there will be more political shocks to come. Both proclaim the reassertion of politics and the (nation) state against the might of the global markets, supposedly in the name of the 'sovereign people.' But this is not happening in the way that most western critics of global market capitalism would have wanted. The new proponents of nationalism and protectionism are still backed, behind the scenes, by corporate power, particularly 
in the US, where President Trump has already stuffed his administration with the same Wall Street big moneymen he derided during the election complain. The resurgent Leviathan slouches in from the Right, not the Left.

It may be that some new technological breakthrough will break the economic impasse we seem to have reached. There may be a new general purpose technology like, in their time, steam power, electrification, and the transistor which enabled the micro-processor revolution, modern computing and the internet. Some think that artificial intelligence and robotisation will be of this order. ${ }^{16}$ They would certainly offer technological improvements in a wide range of new products and processesrather more so than the often paltry inventions of the digital economy in our era, like facebook, and the rest of the social media. But for many economists they also seem likely to be a massive job killers, particularly when robots start designing and building new robots. We are hardly ready for such a massive labour displacement when the world population continues its rapid rise.

The overall outlook in the UK, as in the developed world generally, is bleak for most people-of all ages. But we can expect that the political elites in the UK, at least, will continue, as they have done since the crisis, to ensure that the young carry the heaviest burden.

\section{Gerontocracy and Politics}

We are living in an ageing society which increasingly resembles gerontocracy-a society where power lies with the old. Age-related inequalities in political power are growing and for the foreseeable future advantage the baby-boomer generation over successor generations. This is partly because some birth cohorts are bigger than others and the baby boomers were a particularly large generation, thus having inflated power within the political process. But it is mostly because the electorate generally is ageing due to longer life expectancy. The median age of the electorate has been rising since the 1990s, with 44 being the median age in the 1991 election and 46 in the 2010 election. Craig Berry's demographic projections for the Intergenerational Foundation suggest that the electorate will continue to age at least until 2051, so that the median age rises to 47 in $2021 ; 50$ in 2041; and 51 in 2051. ${ }^{17}$

It is also well-known that older age groups are more likely to register and to turn-out in elections. According to MORI the actual turn-out 
by age group in 2010 was 44 percent for $18-24 s ; 55$ percent for $25-34$ s, compared with 73 percent for $55-64 \mathrm{~s}$ and 76 percent for the over $65 \mathrm{~s} .{ }^{18}$ The over $65 \mathrm{~s}$ were almost twice as likely to vote as $18-24$ year olds. This means that the actual voting power of older groups relative to younger ones tends to be even higher than their relative electoral strength. The median actual voter in 2010 was 49 , whereas the median member of the electorate was 46. According to Berry's projections, based on the recent turn-out rates of different age groups, the median actual voter will be 52 in 2021 and 54 in 2051. People with different types of housing tenure also show a differential propensity to vote. In 2010, 89 percent of outright owners voted; 87 percent of mortgagees; 78 percent of social housing tenants; and only 56 percent of private renters. ${ }^{19}$ Given that young people are increasingly likely to be renting privately, and make up the majority of private renters, this also bodes badly for the 'voting power' of younger people.

The ageing of the electorate matters because voter political preferences vary by age and because there is a degree of 'generational selfishness' in voting patterns. Furlong and Cartmel's analysis of the 2009/2010 British Election Survey showed clear age-related patterns on a number of issues. Amongst Millennial respondents, for instance, 57 percent of females and 49 percent of males listed unemployment amongst the three most important issues. Amongst baby boomers only 40 percent of women and 33 percent of men did so. ${ }^{20}$ Other more recent analyses of age biases in policy preferences, also show older people being more likely to support the NHS than younger people, and younger people more likely to prioritise education. ${ }^{21}$ Older voters were, of course, much more likely to support Brexit than younger voters. With the increasing power of the grey vote, and a mainstream media which reflects their preferences, it is highly likely that governments will favour policies which appeal to these demographics.

In recent years government pandering to the grey vote has become, arguably, ever more explicit. Recent governments have prioritised spending on health, while cutting back on services for young children (Sure Start) and adolescents (further education, the Careers Service, youth clubs etc.); they have maintained a 'triple lock' on pensions whilst driving down the value of other benefits (working family tax credits; education maintenance allowances; housing benefits) which are used more by the young; they have continued to subsidize TV licenses and winter fuel costs for those over 65s, even though this age group is now on average better off than those in their 20s; and they have kept interest rates and inflation low, which benefits older people by supporting the growth 
in the value of the homes, and by helping to maintain the real value of the savings, even where the interest accumulated is low. At the same time, governments have failed to regulate the private housing market on which young people are more dependent. Even the much detested 'spare room tax' contains exemptions for older people. Rising tuition fees and living costs for students, paid from student loans, saddles new generations with high levels of debt, but other policies were available for making graduates contribute more for the education higher education from which they benefit. The proposals for a proper graduate tax to be levied on all graduate tax payers who had studied free of charge in English universities, would have been much less discriminatory by age, as well as by social class, but was never seriously considered.

Given the increasing age-bias of government policies it is hardly surprising that young people are less and less inclined to vote. It is not so much that they are 'apathetic' or 'disinterested' in politics, as in the usual media stereotype. It is more a question of mainstream political parties having nothing to say to their interests. Young people feel they are not represented. Henn and Ford's survey of 18 year olds in 2011 found 63 percent of respondents claiming to be 'interested in politics.' Yet over half agreed that 'young people like me have no say in what Government does' (with 14 percent disagreeing) and 61 percent agreed that they had 'little or no influence on decisions made on their behalf by governments'. Over half of the respondents believed that governments treat young people unfairly ( 15 percent disagreed). ${ }^{22}$ The findings of our 2014 CELS survey broadly concurred with this picture of young people remaining engaged in political issues but demoralised by their lack of voice in electoral politics (Keating et al. 2015).

The ageing of the British electorate is likely to continue to deepen age-related inequalities in (electoral) political power as time goes on. So long as mainstream political parties look no further than winning the next election, and respond only to the messages from focus groups and pollsters on how to fashion their policies to maximise electoral gains, governments are likely to continue to implement measures which reduce young people's opportunities and deepen the age-related inequalities we have discussed throughout this book.

The Millennials will have been a particularly unlucky generation, not just because of the material circumstances of period in which they were born and grew up, but also because their political power has been eclipsed by an ageing electorate. The generation which follows them may do no better. But the coming of the gerontocratic society portends stark 
changes not just for today's and tomorrow's young people, but for society as a whole. Younger people tend to want to invest in the futurethey and their children are the future. Their elders want to enjoy what they have left and focus on the shorter horizon. Arguably, it is only the intergenerational bond which mitigates the presentism of the elderly. ${ }^{23}$ If this is starting to weaken, then an individualistic and conservative gerontocratic state would take less and less care to invest in the future.

This electoral arithmetic certainly looks bleak. However, there is another scenario to counter this pessimistic vision. It focuses not so much on the divide between the young and the old, but on what is happening in between and on what one may call 'youth crisis age creep'. Older voters may continue to dominate electoral politics but still almost half of the electorate will remain under 50. As time goes on, that younger half of the electorate, including those in early middle age, may well come to share more common interests, as the disadvantages currently experienced by 20 somethings become also the problems of those in their 40 s.

In ten years time, the current generation in their 20 s and early 30 s begin to reach early middle age. If they are still mostly unable to buy houses and struggling to meet their rental and student loans payments; if many have still not achieved jobs commensurate with their educational qualifications and are 'just managing' in precarious jobs with declining conditions and pay; and if those coming behind are doing no better; then a powerful new electoral alliance could emerge across age groups, capable of challenging the power of the gerontocratic electorate.

Radical policies on housing-such as capital gains tax on first homes sales; council tax reforms; re-regulation of the rental sector-which currently appeal mostly to younger age groups, might then be in the interests of wide swathes of the electorate under 45. A small increment in income tax for graduates, in return for the writing off of their student debt, may seem like a good deal to the 40 something graduates with families who are still paying off student loans at the same time as paying high rents and mortgages. Equally, as precarious working becomes the norm across age groups, there might be substantial majorities in favour of labour market reform to return stability and dignity to working life.

These voices would have to be heard. The media could not stereotype this younger half of the adult population as lazy or disengaged youngsters. They would now be the majority of the economically active, whose labour and taxes were paying the pensions and care of those in older age. 
They would still be the future-but also the main guarantors of what's left of the current social system. A lot will depend on how their political aspirations evolve over the turbulent years into which we now enter.

Open Access This chapter is licensed under the terms of the Creative Commons Attribution 4.0 International License (http://creativecommons.org/licenses/ by $/ 4.0 /$ ), which permits use, sharing, adaptation, distribution and reproduction in any medium or format, as long as you give appropriate credit to the original author(s) and the source, provide a link to the Creative Commons license and indicate if changes were made.

The images or other third party material in this chapter are included in the chapter's Creative Commons license, unless indicated otherwise in a credit line to the material. If material is not included in the chapter's Creative Commons license and your intended use is not permitted by statutory regulation or exceeds the permitted use, you will need to obtain permission directly from the copyright holder.

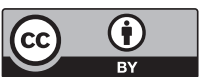

